\title{
CONTROL OF POSTHARVEST BROWN ROT OF SWEET CHERRIES AND PEACHES WITH CHEMICAL AND HEAT TREATMENTS
}

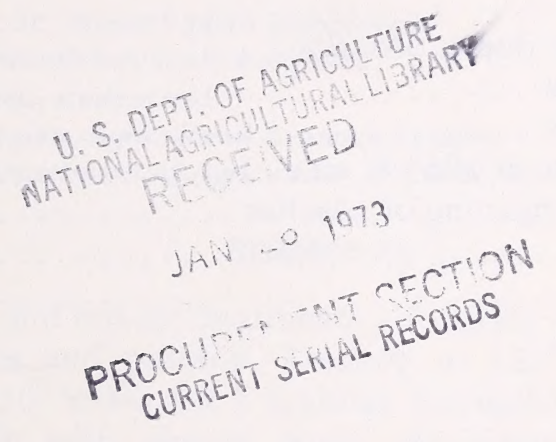

Marketing Research Report No. 979

Agricultural Research Service

UNITED STATES DEPARTMENT OF AGRICULTURE 



\section{Historic, archived document}

Do not assume content reflects current scientific knowledge, policies, or practices. 


\section{CONTENTS}

Page

Summary ....................... 1

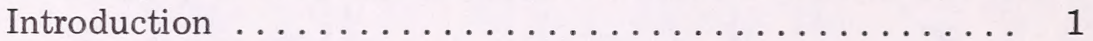

Materials and methods .................. 2

Results ........................ 4

Decay of cherries due to Monilinia ............ 4

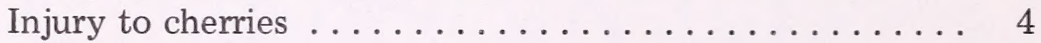

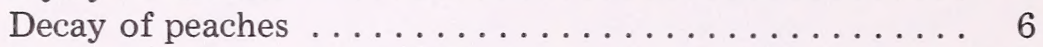

Fruit temperature in $105^{\circ} \mathrm{F}$. air . . . . . . . . . . 8

Appearance and ripening of peaches .......... 8

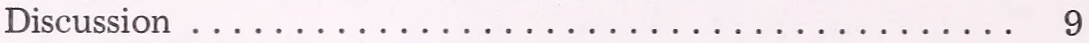

Literature cited ..................... 11

This publication reports research involving pesticides. It does not contain recommendations for their use, nor does it imply that the uses discussed here have been registered. All uses of pesticides must be registered by appropriate State and/or Federal agencies before they can be recommended.

CAUTION: Pesticides can be injurious to humans, domestic animals, desirable plants, and fish or other wildlife -- if they are not handled or applied properly. Use all pesticides selectively and carefully. Follow recommended practices for the disposal of surplus pesticides and pesticide containers.

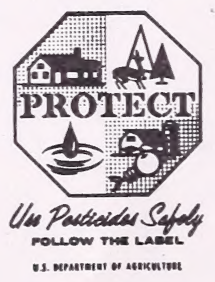

Washington, D.C.

Issued December 1972 


\section{CONTROL OF POSTHARVEST BROWN ROT OF SWEET CHERRIES AND PEACHES WITH CHEMICAL AND HEAT TREATMENTS}

By W.L. Smith, Jr., research plant pathologist, R. W. Penny, research mechanical engineer, and R. Grossman, student aid, Northeastern Region, Agricultural Research Service, United States Department of Agriculture, Beltsville, Md.

\section{SUMMARY}

Hot-water and hot-air treatments effectively controlled decay in sweet cherries and peaches. Treating in $125^{\circ} \mathrm{F}$. water for 2.5 minutes or $115^{\circ}$ water for 5 minutes decreased the percentage of decayed fruit with almost equal effectiveness. Treatment in $115^{\circ}$ water for 2.5 minutes was somewhat less effective. The addition of 100 p.p.m. methyl 1-(butylcarbamoyl)2-benzimidazolecarbamate (benomyl) to $115^{\circ}$ water was more effective in controlling decay of cherries than treatment in $115^{\circ}$ water only for a 2.5-minute exposure.

Injury sometimes occurred on fruit exposed to air near 100 percent relative humidity at $125^{\circ} \mathrm{F}$. for 30 minutes and to fruit dipped in suspensions of benomyl in $125^{\circ}$ water. Exposing fruit to $105^{\circ}$ air of high relative humidity for 24 hours controlled decay about as effectively as the best of the brief hot-water treatments. When the relative humidity during the $105^{\circ}$ exposure was high ( 85 to 95 percent), decay was less prevalent than when it was low (37 percent). Peaches exposed 24 hours to $105^{\circ}$ air of high relative humidity ripened normally at $65^{\circ}$; those exposed to $105^{\circ}$ air of low relative humidity were badly shriveled.

\section{INTRODUCTION}

Brown rot, caused by Monilina fructicola (Wint.) Honey, is a serious postharvest disease of sweet cherries and peaches. Fruits may be infected in the orchard before harvest or in contaminated containers or packing houses after harvest. Control of this disease, 
therefore, cannot depend on proper orchard practices alone. After harvest, low-temperature refrigeration, chemical treatments, and heat treatments are the principal methods for controlling decay of most produce. Both postharvest chemical and heat treatments and a combination of the two have been extensively tested to control postharvest decay of peaches $(2,3,4,5,6,10,11,13,15,16,17$, $19,20,21){ }^{1}$ With sweet cherries, decay is controlled mainly by low-temperature refrigeration or high concentrations of carbon dioxide $(1,7,8)$. Postharvest chemical treatments of cherries have been tried only to a limited extent $(12,14)$. To date, no publications on heat treatments to control postharvest decays of this fruit are known.

In the United States, heat treatments to control postharvest decays of peaches and other fruits have been limited mostly to hot-water treatments or heated chemical suspensions $(15,17,20$, 21). In Australia, on the other hand, exposing peaches to $105^{\circ} \mathrm{F}$. air for 24 hours is the major heat treatment tested $(9,18)$ and used commercially. This study compares the effectiveness of unheated and heated suspensions of chemicals with hot-water or hot-air treatments to control decay in sweet cherries and of hot-water or hot-air treatments to control decay in peaches.

\section{MATERIALS AND METHODS}

'Royal Anne', 'Cumberland', and 'Windsor' sweet cherries, grown commercially in Maryland, were used in most of these tests. At harvest many of these fruits had numerous splits or cracks and some of them had been injured by hail. Since such fruit could not be evaluated accurately for injury due to treatment, 'Bing' cherries from Washington and Oregon, free of injury, were used for these tests. Duplicate lots of 25 cherries each were used for each treatment in all tests.

'Sunhaven', 'Redhaven', 'Blake', 'Sunhigh', and 'Loring' peaches, obtained from commercial orchards in Maryland and Virginia, were used in these tests. All fruit were sorted before the tests for uniformity of size and freedom from diseases or other blemishes. Twenty fruit were used per treatment in all except one test in which 15 fruit were used.

Both cherries and peaches were inoculated 24 hours before treatment by dipping the fruit into a beef-peptone broth suspension containing about $9 \times 10^{4}$ Monilinia spores per milliliter. Peaches were also inoculated with Rhizopus stolon-

\footnotetext{
${ }^{1}$ Italic numbers in parentheses refer to Literature Cited, p. 11.
} 
ifer (Ehr ex. Fr.) Vuill. by dipping them into a suspension containing about $21 \times 10^{4}$ spores per milliliter. Neither the cherries nor peaches were artificially injured before inoculation with Monilinia spores, but a shallow cut, resembling fingernail injury, was made on each cheek of peaches inoculated with Rhizopus spores. After inoculation all fruits were held at $65^{\circ} \mathrm{F}$.

For treatments, fruits were submerged into a constant temperature hot-water bath at $115^{\circ} \mathrm{F}$. for 2.5 or 5 minutes or at $125^{\circ}$ for 2.5 minutes. In addition, cherries were treated with suspensions of methyl 1-(butylcarbamoyl)-2-benzimidazolecarbamate (benomyl) at 100 and 500 p.p.m. in $70^{\circ}$ water and at 100 p.p.m. in $115^{\circ}$ and $125^{\circ}$ water.

Fruits were also treated with hot air. Some were placed in a closed glass chamber and high-humidity air (95 to 100 percent) constantly circulated around them. Temperature within the glass chamber was maintained at $115^{\circ}$ or $125^{\circ} \mathrm{F}$. with $15-$ or 30 -minute exposures. Others were held at $105^{\circ}$ for 24 hours in metal drums sealed with glass lids. Relative humidity $(\mathrm{RH})$ within a drum was controlled with a lithium chloride electric hygrometer in conjunction with a humidistat. Desired relative humidities within the different drums were 75,85 , and 95 percent. To obtain these relative humidities, a pump circulated air through heated water and into the respective drum when the relative humidity within that drum was below the setting of the humidistat. A second pump added dry air when the relative humidity was at, or above, the desired setting. The relative humidity level in each drum was monitored at intervals and at the end of each test by plugging the lithium chloride saturated element into a hygrometer indicator. In each test, on additional lot of peaches was placed at the ambient relative humidity of the $105^{\circ}$ room.

In the test chambers the pulp and subsurface temperatures of the fruit were measured at intervals by thermocouples embedded near the pit or just under the skin of the peaches. These thermocouples were connected to a 24-point temperature recorder. Temperatures of fruit in the ambient air were taken with thermocouples at the end of the tests.

Both cherries and peaches were held at $65^{\circ} \mathrm{F}$. and about 90 percent relative humidity after treatment. Six separate tests were conducted with cherries and eight with peaches. All data on decay were analyzed by the analysis of variance and the means were compared by using the Duncan Multiple-Range Test.

The effect of the various treatments on softening of peaches was determined in five tests by using the Magness-Taylor pressure tester with a 5/16-inch plunger. 


\section{RESULTS}

\section{Decay of Cherries due to Monilinia}

After 3 days at $65^{\circ} \mathrm{F}$, a very low percentage of decay developed on untreated cherries (dry or wet checks) and none on the treated fruit.

After 6 and 9 days at $65^{\circ} \mathrm{F}$., a high percentage of the untreated fruit developed brown rot (table 1 ). At each reading period decay of fruit given each of the treatments was significantly less than that of either check. Differences in decay developing on cherries treated with 100 or 500 p.p.m. benomyl were not significant. Cherries treated with heated suspensions of benomyl usually developed significantly less decay than those treated with unheated suspensions. When benomyl was added to $115^{\circ}$ water and the fruit given 2.5-minute exposure, less decay developed on the cherries than on those treated with $115^{\circ}$ water only. Fruit given the other hot-benomyl treatments and that treated with $115^{\circ}$ water for 5 minutes or $125^{\circ}$ water for 2.5 minutes developed about the same percentage of decay. Decay of cherries given the hot-air treatments did not differ significantly from those treated with hot water for 6 days after treatment. However, after 9 days at $65^{\circ}$ most of the hot-water treated cherries developed less decay than the hot-air treated fruit.

\section{Injury to Cherries}

All cherries, treated and untreated, showed some degree of injury after 6 or 9 days at $65^{\circ} \mathrm{F}$. The injury developed as small, round, slightly sunken areas giving the severely injured fruit a stippled appearance. Sometimes the skin was bleached. This injury was more severe on locally grown cherries that were injured before harvest than on the western grown Bing cherries. Locally grown fruit treated in $115^{\circ}$ water for 5 minutes, and in $125^{\circ}$ water with or without benomyl for 2.5 minutes, and in $125^{\circ}$ air for 30 minutes had the most severe injury. All locally grown varieties had about the same degree of injury from the heat treatments. Bing cherries treated in $125^{\circ}$ air were severely injured and unsalable. Somewhat less severe injury developed in Bing cherries treated in $115^{\circ}$ water for 5 minutes, $125^{\circ}$ water with benomyl, and $105^{\circ}$ air and 80 percent relative humidity for 24 hours. Injury on the Bing 
Table 1.-Decay at $65^{\circ} \mathrm{F}$. of sweet cherries inoculated with Monilinia fructicola spores 24 hours before treatment ${ }^{1}$

\begin{tabular}{|c|c|c|}
\hline \multirow{2}{*}{ Postharvest treatment } & \multicolumn{2}{|c|}{ Decay during- } \\
\hline & 6 days & 9 days \\
\hline & Percent & Percent \\
\hline \multicolumn{3}{|l|}{ Checks: } \\
\hline Dry (no treatment) . . . . . . . . . . & $74.3 \mathrm{a}$ & $83.0 \mathrm{a}$ \\
\hline Wet $\left(70^{\circ} \mathrm{F}\right.$. water $) \ldots \ldots \ldots$ & $71.0 \mathrm{a}$ & $85.0 \mathrm{a}$ \\
\hline \multicolumn{3}{|l|}{ Benomyl treatment, $70^{\circ} \mathrm{F}$. water } \\
\hline 500 p.p.m . . . . . . . . . . & $15.5 \mathrm{bcd}$ & 31.7 bcde \\
\hline 100 p.p.m $\ldots \ldots \ldots \ldots \ldots$ & $27.0 \mathrm{bc}$ & $41.7 \mathrm{bc}$ \\
\hline \multicolumn{3}{|l|}{ Hot-water treatments } \\
\hline \multicolumn{3}{|l|}{$115^{\circ} \mathrm{F}$. water for } \\
\hline Water only . . . . . . . . . . & $29.7 \mathrm{~b}$ & $51.7 \mathrm{~b}$ \\
\hline $\begin{array}{l}\text { Plus benomyl } 100 \text { p.p.m. . . . . } \\
5.0 \text { min.: }\end{array}$ & $7.0 \mathrm{~d}$ & 19.8 def \\
\hline Water only . . . . . . . . . . & 1.3 & 11.7 \\
\hline $\begin{array}{l}\text { Plus benomyl } 100 \text { p.p.m } \ldots \ldots \\
125^{\circ} \text { water for } 2.5 \text { min.: }\end{array}$ & 2.3 & 8.3 \\
\hline Water only $\ldots \ldots \ldots \ldots \ldots \ldots$ & 1.3 & 5.3 \\
\hline Plus benomyl 100 p.p.m . . . . . . & 2.0 & 2.7 \\
\hline Hot-air treatments & & \\
\hline $115^{\circ}$ F. air, 95 pct. $\mathrm{RH}$, for $30 \mathrm{~min} .$. & $9.0 \mathrm{~cd}$ & 29.3 cde \\
\hline $\begin{array}{l}125^{\circ} \mathrm{F} \text {. air, } 95 \text { pct. } \mathrm{RH} \text {, for } 30 \mathrm{~min} . \\
105^{\circ} \mathrm{F} \text {. air for } 24 \text { hours } \\
\text { and relative humidity }{ }^{2}-\end{array}$ & $8.3 \mathrm{~cd}$ & 38.0 bcd \\
\hline 80 pet $\ldots \ldots \ldots \ldots \ldots \ldots$ & $9.3 \mathrm{~cd}$ & $46.7 \mathrm{bc}$ \\
\hline 89 pet $\ldots \ldots \ldots \ldots \ldots \ldots$ & $6.7 \quad \mathrm{~d}$ & $39.0 \mathrm{bcd}$ \\
\hline 97 pct $\ldots \ldots \ldots \ldots \ldots \ldots \ldots \ldots \ldots \ldots \ldots \ldots \ldots$ & $16.3 \mathrm{bcd}$ & $39.7 \mathrm{bcd}$ \\
\hline
\end{tabular}

${ }^{1}$ Mean of 6 tests of duplicate lots of 25 cherries each. Means are compared by the Duncan Multiple-Range Test. In the individual columns, means followed by a letter or letters in common are not significantly different at the 5-percent level.

${ }^{2}$ Readings on relative humidity made with a hygrometer indicator. 
cherries receiving the other treatments did not differ significantly from that on wet or dry checks.

\section{Decay of Peaches}

All of the treated fruit developed less monilinia and rhizopus decay than the untreated fruit (wet and dry checks) during the first 3 days at $65^{\circ} \mathrm{F}$. (tables 2 and 3). Decay developing on fruit with each of the heat treatments was about equal. After 6 days

Table 2.-Decay at $65^{\circ} \mathrm{F}$. of peaches inoculated with Monilinia fructicola spores 24 hours before treatment ${ }^{1}$

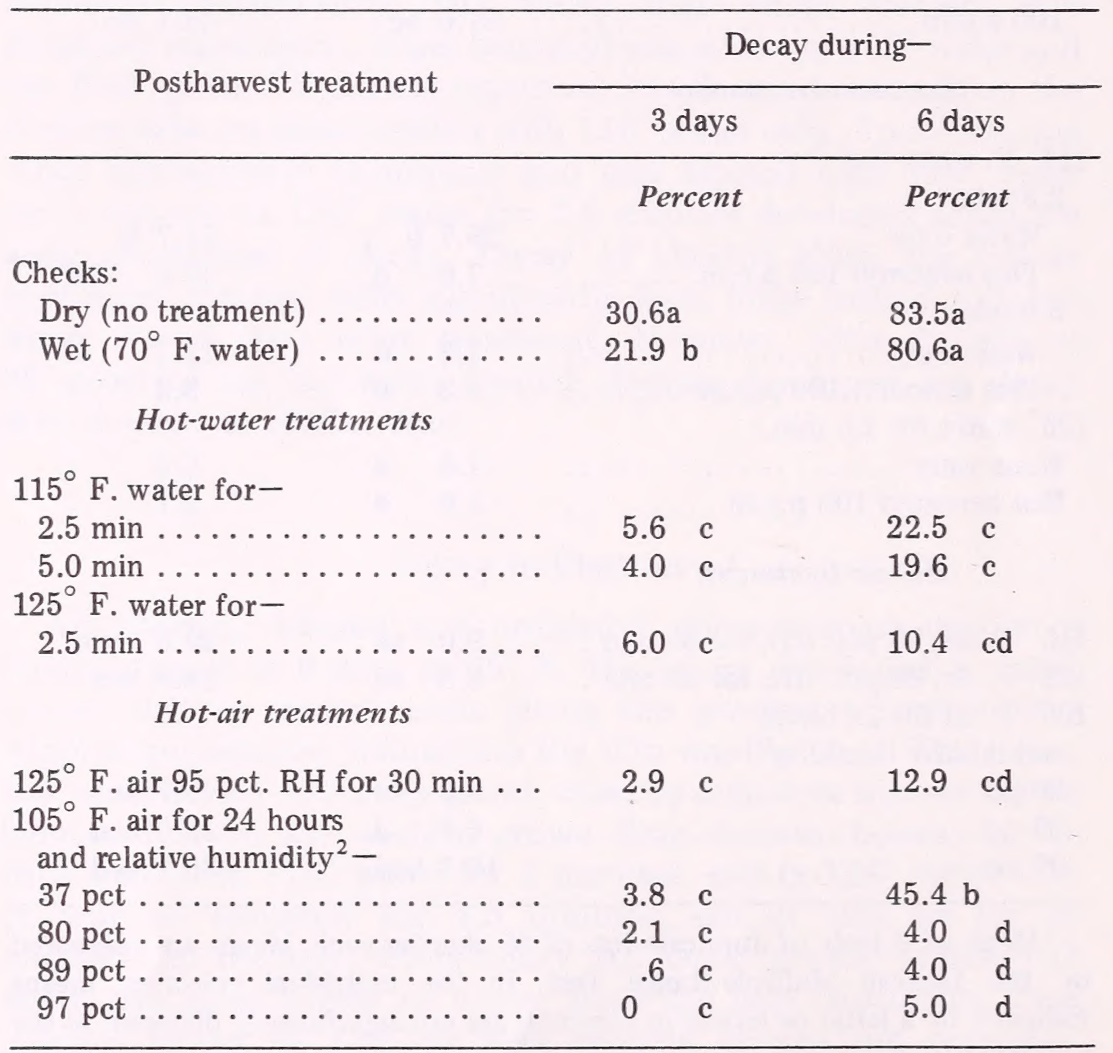

${ }^{1}$ Means of 8 tests with 15 to 20 fruit per treatment. Means are compared by the Duncan Multiple-Range Test. In the individual columns, means followed by a letter or letters in common are not significantly different at the 5 -percent level.

\footnotetext{
${ }^{2}$ Readings on relative humidity made with hygrometer indicator.
} 
Table 3.-Decay at $65^{\circ} \mathrm{F}$. of peaches inoculated with Rhizopus stolonifer 24 hours before treatment ${ }^{1}$

\begin{tabular}{|c|c|c|}
\hline \multirow{2}{*}{ Postharvest treatment } & \multicolumn{2}{|c|}{ Decay during- } \\
\hline & 3 days & 6 days \\
\hline & Percent & Percent \\
\hline \multicolumn{3}{|l|}{ Checks: } \\
\hline Dry $($ no treatment) ............ & $87.5 \mathrm{a}$ & $95.0 \mathrm{a}$ \\
\hline Wet $\left(70^{\circ} \mathrm{F}\right.$. water $) \ldots \ldots \ldots \ldots$ & $77.5 \mathrm{a}$ & $89.4 \mathrm{a}$ \\
\hline \multicolumn{3}{|l|}{ Hot-water treatments } \\
\hline \multicolumn{3}{|l|}{$115^{\circ} \mathrm{F}$. water for- } \\
\hline $2.5 \min \ldots \ldots \ldots \ldots \ldots \ldots \ldots$ & $9.3 \mathrm{~b}$ & $28.1 \mathrm{c}$ \\
\hline $5.0 \min \ldots \ldots \ldots \ldots \ldots \ldots$ & $2.3 \mathrm{~b}$ & $18.1 \mathrm{~cd}$ \\
\hline $125^{\circ} \mathrm{F}$. water for- & & \\
\hline $2.5 \min \ldots \ldots \ldots \ldots \ldots \ldots$ & $2.1 \mathrm{~b}$ & $13.5 \mathrm{~cd}$ \\
\hline \multicolumn{3}{|l|}{ Hot-air treatments } \\
\hline $\begin{array}{l}125^{\circ} \mathrm{F} \text {. air } 95 \text { pct. } \mathrm{RH} \text { for } 30 \mathrm{~min} \ldots \\
105^{\circ} \mathrm{F} \text {. air for } 24 \text { hours } \\
\text { and relative humidity }{ }^{2}-\end{array}$ & $1.3 \mathrm{~b}$ & $17.9 \mathrm{~cd}$ \\
\hline 37 pet $\ldots \ldots \ldots \ldots \ldots \ldots \ldots$ & $8.4 \mathrm{~b}$ & $48.4 \mathrm{~b}$ \\
\hline 80 pct $\ldots \ldots \ldots \ldots \ldots \ldots \ldots \ldots$ & $1.6 \mathrm{~b}$ & $6.9 \mathrm{~d}$ \\
\hline 89 pct $\ldots \ldots \ldots \ldots \ldots \ldots \ldots$ & $.6 \mathrm{~b}$ & $6.3 \mathrm{~d}$ \\
\hline 97 pct $\ldots \ldots \ldots \ldots \ldots \ldots \ldots$ & $1.3 \mathrm{~b}$ & $12.9 \mathrm{~cd}$ \\
\hline
\end{tabular}

${ }^{1}$ Means of 8 tests with 15 to 20 fruit for each treatment. Means are compared by the Duncan Multiple Range Test. In the individual columns, means followed by a letter or letters in common are not significantly different at the 5-percent level.

${ }^{2}$ Readings on relative humidity made with hygrometer indicator.

holding at $65^{\circ}$, however, differences in decay developing on fruit given some of the different treatments were very apparent.

Fruit treated in $105^{\circ} \mathrm{F}$. air with relative humidity of 80 percent and above for 24 hours and held for 6 days at $65^{\circ}$ developed significantly less decay than when the relative humidity was low during the same exposure period. These 24-hour exposures to high humidity $105^{\circ}$ air usually reduced the development of decay more, though not significantly more, than the $125^{\circ}$ water or air treatments. Though fruit treated with $125^{\circ}$ water developed less decay than those treated in $115^{\circ}$ water, the difference in decay 
was not significant. Fruit treated with $105^{\circ}$ air of low relative humidity developed significantly less decay than either check but significantly more decay than other treatments if held for 6 days after treatment.

\section{Fruit Temperature in $105^{\circ} \mathrm{F}$. Air}

In five or eight tests air temperature within each of the drums was about $105^{\circ} \pm 2^{\circ} \mathrm{F}$. within 4 hours of the start of the tests. After the original rise in temperatures, the temperatures within the drums remained relatively constant. Temperatures of peaches increased more slowly. Within an hour these temperatures increased from about $70^{\circ}$ to over $85^{\circ}$ and then rose at a slow but constant rate until after 12 hours when fruit temperatures near the pit averaged $103^{\circ} \pm 2^{\circ}$. They remained at this temperature for the rest of the 24-hour period.

In the other three tests air temperatures rose more rapidly in the drums, and after 12 hours they averaged $110^{\circ} \pm 2^{\circ} \mathrm{F}$. Temperatures of fruit in these tests increased accordingly and during the final 12 hours were about 3 degrees above the desired $105^{\circ}$.

While the peaches were held in drums in high humidity air of about $105^{\circ}-\mathrm{F}$., pulp temperatures in the various replicates varied considerably, especially during the final 19 hours. During this period pulp temperatures of some lots of fruit averaged $102^{\circ}$ whereas other lots averaged up to $108^{\circ}$. Decay of fruit after transfer to $65^{\circ}$ was about the same regardless of the pulp temperature of the fruit during the hot-air exposure.

Temperature of the peaches in ambient air ( 37 percent $\mathrm{RH})$ in the $105^{\circ} \mathrm{F}$. room apparently increased more slowly. After a 24-hour exposure, the fruit temperature just under the skin averaged $94.8^{\circ}$. Temperature under the skin of the fruit in the various tests ranged from a high of $100^{\circ}$. to a low of $91^{\circ}$.

At the end of the tests, readings were made on the relative humidity in the three drums at $105^{\circ} \mathrm{F}$. The mean of these readings was 80.4 percent, 89.8 percent, and 97.3 percent relative humidity.

\section{Appearance and Ripening of Peaches}

Injury in the form of tan spots, streaking, or mottle sometimes occurred on a few peaches of each variety given each heat treatment except those treated in $115^{\circ} \mathrm{F}$. water for 2.5 minutes. Normally, the injury detracted only slightly from the general 
appearance of the fruit in the particular treatment. Peaches treated in $125^{\circ}$ air for 30 minutes were injured most often. Sometimes this injury was severe enough to detract from the general appearance of the fruit. The fruit held in $105^{\circ}$ air of high relative humidity for 24 hours usually closely resembled the check fruit. Ground color or red blush was no different between these fruit and the unheated fruit. However, fruit held at $105^{\circ}$ in low ambient relative humidity always was badly shriveled.

Peaches treated with hot water, or $125^{\circ} \mathrm{F}$. air and then placed at $65^{\circ}$ air, ripened at about the same rate as the unheated peaches. During the first 24 hours, the pressure test of the unheated peaches at $65^{\circ}$ changed from about 6.8 to 2.3. Fruit held at $105^{\circ}$ also ripened. When peaches were removed from $105^{\circ}$ air, the pressure test had changed from about 6.8 to 2.7 for fruit held at 37 percent relative humidity, 3.2 at 80 percent, 3.5 at 89 percent, and 3.7 at 97 percent. When these fruits were transferred to $65^{\circ}$ within 2 days, they were the same pressure test as the unheated fruit.

\section{DISCUSSION}

Prevention of or reduction in development of decay on inoculated fruit depends on the effectiveness of a treatment in destroying decay-producing organisms on and under the skin of the fruit. In these studies the fruit artificially inoculated 24 hours before treatment resembled fruit inoculated in the orchard 24 hours before harvest. In both inoculations, spores of the brown rot organism would have time to germinate and penetrate beneath the fruit skin. In tests on cherries treated with benomyl suspensions at $70^{\circ} \mathrm{F}$., good control of decay was obtained on fruit held 6 days at $65^{\circ}$, but less acceptable control when they were held 9 days. This finding could indicate that the $70^{\circ}$ benomyl suspension is toxic to organisms on the surface of the fruit, but organisms under the skin continue to grow and eventually produce external symptoms.

In heated suspensions, on the other hand, benomyl effectively controlled brown rot on cherries after both 6 and 9 days in $65^{\circ} \mathrm{F}$. air. This control, however, usually was not significantly different from that obtained with hot water alone. A similar effect was found with heated and unheated suspensions of benomyl to control brown rot of peaches (15). ${ }^{2}$ In all experiments, hot-water

\footnotetext{
${ }^{2}$ Benomyl is registered for use on peaches and nectarines with a residue tolerance of 15 p.p.m. established. It is not approved for use on cherries.
} 
treatments that were extremely effective in controlling brown rot of cherries held 6 days at $65^{\circ}$ air also effectively controlled decay when the fruit was held 9 days at the same temperature. This finding indicates that the water temperature and exposure time were sufficient to destroy the decay-producing organism on and under the skin of the fruit.

In these studies injury to the cherries was difficult to evaluate. Apparently, if cherries have any type of injury, hot-water, heated chemical suspensions, or hot-air treatments are apt to intensify this injury. In limited tests with uninjured cherries, the fruit was seriously injured only when it was exposed to nearly saturated air at $125^{\circ} \mathrm{F}$. or when benomyl was used in $125^{\circ}$ water. Most of the hot-water or hot-air treatments used in these tests show promise for controlling decay in sweet cherries. These treatments require further testing to better evaluate the causes of injury to the fruit.

Data obtained on hot-air treatments for the control of decay of peaches caused by Monilinia confirm the work of Australian researchers $(9,18)$. These data extend the findings of these researchers by showing the importance of relative humidity during treatment. If the relative humidity during treatment was above 80 percent in about $105^{\circ} \mathrm{F}$. air, brown rot and rhizopus rot development on peaches was reduced about equivalent to the best hot-water treatments. Treating sweet cherries in hot air also gave good control of decay. In the studies reported here, control of decay was equally good following treatment in $105^{\circ}$ air at relative humidities of about 80, 89, and 97 percent. Some control of decay was obtained when the relative humidity of the $105^{\circ}$ room was about 37 percent, but it was not as effective as the high relative humidity and the fruit shriveled.

The exact effect of relative humidity on prevention of decay is difficult to determine. In the experiments reported on here, complications developed when fruit with a pulp temperature of $70^{\circ} \mathrm{F}$. was placed in high relative humidity air at $105^{\circ}$. Condensation formed on the fruit during the time the fruit was below the dewpoint temperature, resulting in a saturated condition at the fruit's surface. The effect of the relative humidity of the air on decay, therefore, could not be measured accurately. On the other hand, when $70^{\circ}$ fruit was placed in air of low relative humidity ( 37 percent), the fruit's temperature was close to the dewpoint and in a short time exceeded it. Temperature of this fruit did not increase as much as the fruit placed in high relative humidity air. The chief effect of relative humidity was on increasing fruit temperature. For effective control of decay in 
fruit, pulp temperatures of $101^{\circ}$ and above apparently are necessary. To obtain such temperatures, the relative humidity during the hot-air treatment should be 80 percent or above.

An alternative to the hot-water or chemical treatments for controlling decay in peaches and cherries is to expose the fruit for 24 hours to high-humidity air at $105^{\circ} \mathrm{F}$. Bulk bins or field boxes of fruit from the orchard could be placed directly in a high-temperature, high-humidity room for 24 hours and then moved to another room for ripening. Such a procedure may be especially applicable for canning or processing plants. Peaches handled in this way usually have high temperatures throughout, in contrast to hot-water treated peaches that have high temperatures only under the skin. Nevertheless in these tests with small lots of fruit, peaches treated with hot air ripened at about the same rate as fruit not heated. The Australians, on the other hand, found more rapid ripening in large lots of hot-air treated peaches and recommend that fruit so treated should be cooled to $75^{\circ}$ as quickly as possible (personal correspondence).

\section{LITERATURE CITED}

(1) Brooks, Charles, Bratley, C. O., and McColloch, L. P.

1936. Transit and storage diseases of fruits and vegetables as affected by initial carbon dioxide treatments. U.S. Dept. Agr. Tech. Bul. 519, 24 pp.

(2) Cappellini, R. A., and Stretch, A. W.

1962. Control of postharvest decay of peaches. U.S. Agr. Res. Serv., Plant Dis. Rptr. 46 (1): 31-33.

(3) Daines, R. H.

1965. 2,6-dichloro-4-nitroaniline used in orchard sprays, the dump tank, the wet brusher, and the hydrocooler for control of rhizopus rot of harvested peaches. U.S. Agr. Res. Serv., Plant Dis. Rptr. 49 (4): 300-304.

(4) Dewey, D. H., and McLean, D. C.

1962. Postharvest treatment with 2,6-dichloro-4nitroaniline for fruit rot control on fresh market peaches. Mich. Agr. Expt. Sta. Quart. Bul. 44: 679-683.

(5) DiMarco, G. R., and Davis, B. H.

1957. Prevention of decay of peaches with postharvest treatments. U.S. Agr. Res. Serv., Plant Dis. Rptr. 41: 284-288. 
(6) Eaks, I. L., Eckert, J. W., and Roistacher, C. N.

1958. Ammonia gas fumigation for control of rhizopus rot of peaches. U.S. Agr. Res. Serv., Plant Dis. Rptr. 42: 846-848.

(7) English, H., and Gerhardt, F.

1942. Effect of carbon dioxide and temperature on the decay of sweet cherries under simulated transit conditions. Amer. Soc. Hort. Sci. Proc. 40: 172-176.

(8) Gerhardt, Fisk, and Ryall, A. L.

1939. The storage of sweet cherries as influenced by carbon dioxide and volatile fungicides. U.S. Dept. Agr. Tech. Bul. 631, 20 pp.

(9) Jenkins, P. T., Peggie, I. D., and Tindale, G. B.

1961. Brown rot in canning peaches. A heat therapy control. Plant Path. Waite Agr. Res. Inst. Adelaide Conf. 1 ( 7 ) : 2 .

(10) Luvisi, D. A., and Sommer, N. F.

1960. Polyethylene liners and fungicides for peaches and nectarines. Amer. Soc. Hort. Sci. Proc. 76: 146-155.

(11) McClure, T. T.

1968. Brown rot and rhizopus rots of peaches as affected by hydrocooling, fungicides and temperature. Phytopathology 48: 322-323.

(12) Ogawa, J. M., Lydia, S. D., and Weber, D. J.

1961. 2, 6-dichloro-4-nitroaniline effective against rhizopus fruit rot of sweet cherries. U.S. Agr. Res. Serv., Plant Dis. Rptr. 45: 636-638.

(13)

1968. Efficacy of fungicide 1991 in reducing fruit rot of stone fruits. U.S. Agr. Res. Serv., Plant Dis. Rptr. 52: 722-726.

(14) Pierson, C. F.

1958. Fungicides for reduction of post-harvest decay of sweet cherries. Wash. State Hort. Soc. Proc. 54: 115-116.

(15) Smith, W. L., Jr.

1971. Control of brown rot and rhizopus rot of inoculated peaches with hot water or hot chemical suspension. U.S. Agr. Res. Serv., Plant Dis. Rptr. 55: 228-230. 
(16) Haller, M. H., and McClure, T. T.

1956. Post harvest treatments for reduction of brown and rhizopus rots of peaches. Phytopathology 46: $261-264$.

(17) and Redit, W. H.

1968. Postharvest decay of peaches as affected by hot-water treatments, cooling methods, and sanitation. U.S. Dept. Agr. Market. Res. Rpt. $807,9 \mathrm{pp}$.

(18) Tindale, G. B.. Jenkins, P. T., and Peggie, I. D.

1958. Brown rot in canning peaches. Jour. Dept. Agr. Victoria 56 (2): 107-109.

(19) Van Blaricom, L. O.

1959. The effect on decay of adding various reagents to the water for hydrocooling peaches. S.C. Agr. Expt. Sta. Cir. 124: 1-17.

(20) Wells, J. M.

1970. Postharvest hot water and fungicide treatments for reduction of decay of California peaches, plums, and nectarines. U.S. Dept. Agr. Market. Res. Rpt. 908, 10 pp.

(21) and Gerdts, M. H.

1971. Pre- and postharvest benomyl treatments for control of brown rot of nectarines in California. U.S. Agr. Res. Serv., Plant Dis. Rptr. 55: 69-72. 
U. S. DEPARTMENT OF AGRICULTURE AGRICULTURAL RESEARCH SERVICE NORTHEASTERN REGION

AGRICULTURAL RESEARCH CENTER WEST BELTSVILLE, MARYLAND 20705

OFFICIAL BUSINESS

PENALTY FOR PRIVATE USE, $\$ 300$

Postage \& Fees Paid

U.S. Department of

Agriculture

AGR 101 